\title{
Pápai Páriz Ferenc életmúve a táplálkozástudomány és a dietetika nézőpontjából
}

\author{
Solymosi Dóra dr. ${ }^{1}$ - Molnár Szilvia dr. ${ }^{2}$ - Csajbókné dr. \\ Csobod Éva ${ }^{2}$. Veresné dr. Bálint Márta ${ }^{2}$
}

\author{
${ }^{1}$ Semmelweis Egyetem, Doktori Iskola - Klinikai Orvostudományok, Budapest \\ ${ }^{2}$ Semmelweis Egyetem, Egészségtudományi Kar, Dietetikai és Táplálkozástudományi Tanszék, Budapest
}

A hazai táplálkozás- és élelmezéstudomány kialakulásának, mondhatjuk, hogy az egyik mérföldköve volt Pápai Páriz Ferenc (1. ábra) [1] munkássága a XVII. században. Az ő nevéhez köthető az első olyan orvosi mú, mely kitér a helyes életmódra és ezen belül is az étrendre, valamint az egyes kórállapotoknak megfelelő élelmiszerekre is.

Pápai Páriz Ferenc 1649. május 10-én született Désen (ma Dej, Románia), és 1716. szeptember 10-én halt meg Nagyenyeden (ma Aiud, Románia). Igazi polihisztor volt, a XVII. századi magyar természettudományos szemlélet kialakítója, népszerüsítője. Orvosdoktor, költő, filozófus, a nagyenyedi Kollégium tanára. Több or-

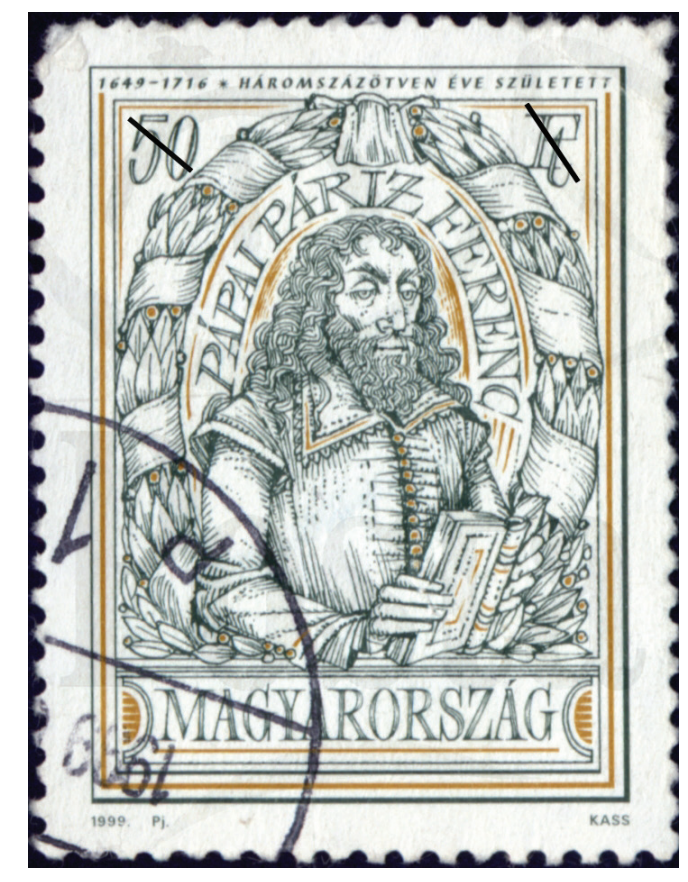

1. ábra

| Pápai Páriz Ferenc bélyegképe (tervező: Kass János) [1] vosi múvet írt latin és magyar nyelven, igazán ismertté azonban a Pax Corporis (Az emberi testnek belsö nyavalyáinak okairól, fészkeiröl, 's azoknak orvoslásának módgyáról való Tracta) címü könyve tette. Emellett írt vallási, egyháztörténeti tárgyú múveket, fordított (német, francia), verseket írt (görög nyelven is), latin-magyar és magyar-latin szótárt szerkesztett, valamint heraldikával is foglalkozott [2-5].

Apja, Páriz Imre, pápai születésű protestáns pap volt, aki Désen kötött házasságot Kávási Borbálával, majd négy gyermekük született: Ferencz, Imre, Pál és Krisztina. A lelkes pap hamar nagy népszerúségre tett szert, II. Rákóczi György Gyulafehérvárra (ma Alba Iulia, Románia) hívta. 1658-ban a tatárok támadása elől kényszerből Kolozsvárra (ma Cluj-Napoca, Románia) települt át a család, majd késóbb innen újra visszatértek Désre. A tatár csapatok új hullámának pusztítása miatt ismét menekülniük kellett. Először Besztercén (ma Bistrița, Románia), majd végül újra Gyulafehérváron éltek [2].

A sorozatos költözések miatt a gyermek, Pápai Páriz Ferenc iskoláskora hányattatott, zaklatott volt. Ennek ellenére amikor arra lehetősége nyílt, tanulmányait kifogástalanul teljesítette, folytatta, ismételte, s mint korában a jó képességü fiatalok, 23 évesen vándordiáknak állt. Anyagi támogatás híján ajánlólevelekre, módos ismerőseire támaszkodott. Boroszlón (egykoron Breslau, ma Wrocław, Lengyelország) át Drezdába, Heidelbergbe, végül Bázelbe jutott, ahol is 1674-ben orvossá avatták. Ezután ösztöndíjas tanársegédként múködött tovább az egyetemen [6-9].

A kor szokásához híven a vándordiákévek után hazatért Erdélybe, ahol családot alapított. Rektori címet kapott, a nagyenyedi Bethlen Kollégiumban tanított (görög nyelv, filozófia), és az udvari orvosi tisztséget is betöltötte. Latin-magyar szótárát (Dictionarium manu- 
ale Latino-Ungaricum et Ungarico-Latinum) feleségének diktálta, hiszen időskorára szinte teljesen elvesztette látását $[6,7,10,11]$.

Pax Corporis (A test békéje) címû mưvét 1690-ben (2. ábra) [12] Kolozsvárott adták ki. Ezután még számos kiadás következett. Az 1701-es lőcsei (ma Levoča, Szlovákia) kiadás volt az utolsó, melyet Pápai Páriz még megélhetett. Halálát követően is több posztumusz (például 1747-ben) (3. ábra) [13] kiadás jelent meg. Jelen tudásunk szerint a Pax Corporisnak összesen tizenegy kiadása készült, a legutolsó 1756-ban [9, 14, 15]. Pápai Páriz idejében a Pax Corporis volt az első, nyomtatásban megjelent, magyar nyelvü orvosi kiadvány. Ez a múve tette igazán ismertté Pápai Páriz Ferencet. A korabeli orvosi irodalomban átütő jelentőséggel bírt, habár a mú számos érdeme még sokáig rejtve maradt a tudomány nemzetközi színtere előtt, hiszen a magyar nyelvet igen

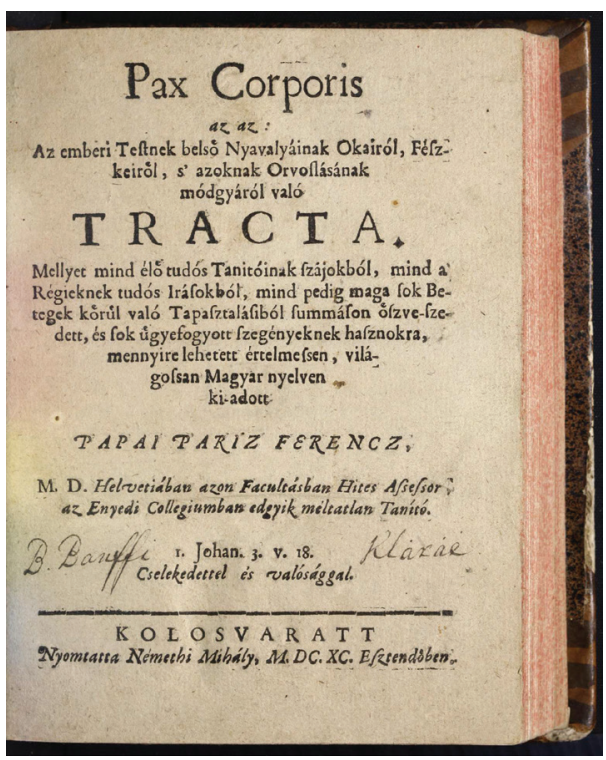

2. ábra

| A Pax Corporis első, 1690. évi kiadása [12]

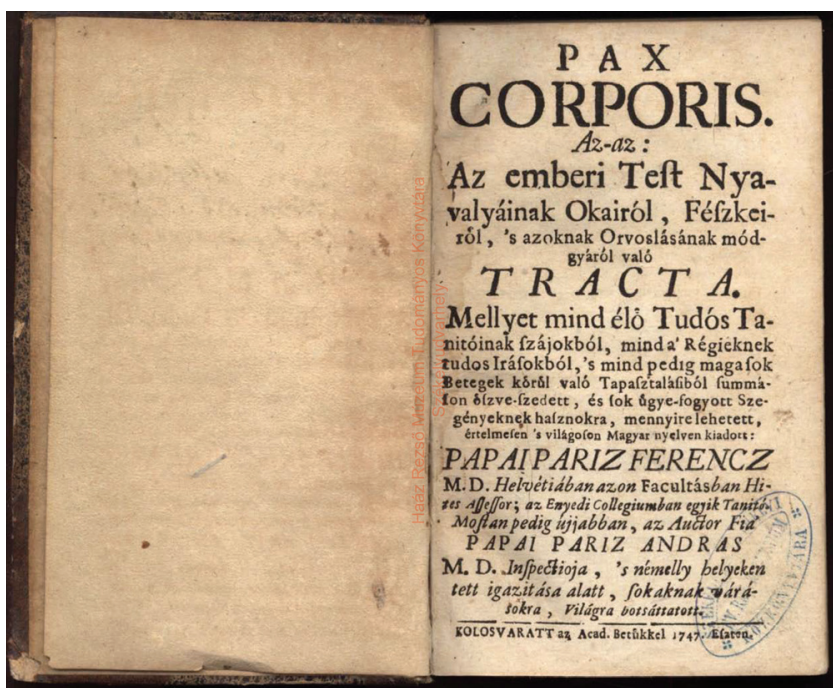

3. ábra

A Pax Corporis 1747. évi kiadása [13] kevesen beszélték. Így történhetett, hogy Pápai Páriz már jóval korábban, 130 évvel James Parkinson előtt leírta a Parkinson-kór jellegzetes tünettanát, ám csak napjainkban figyelt fel erre a tudomány [15-18].

Pápai Páriz Ferenc népszerú, a praktikusságot szem előtt tartó múve támpontul szolgált a családoknak egészségügyi kérdésekben. Már az előszóban („Elöljáró beszéd”) hangsúlyozza, hogy nem tudósoknak, hanem azoknak ír, akik nehezen vagy egyáltalán nem tudnak orvoshoz jutni, s így kénytelenek maguk megoldani testük problémáit. Nyolckötetes múve szervrendszerekre bontva taglalja a betegségeket differenciáldiagnosztikai, etiológiai, tüneti és terápiás szempontból. Az emésztőrendszerrel a negyedik (A gyomornak és bélnek nyavalyái) és az ötödik ( $A$ májnak, lépnek és vesének nyavalyáiról) részben foglalkozik $[15,16]$.

Az ajánlott gyógymódot fóleg gyógynövények jelentették, de a korszellem elmaradhatatlan módszerei - hánytatás, hashajtás, érvágás, izzasztás - is megjelennek. Természettudományos gondolkodását tükrözi, hogy a betegségeket nem büntetésnek tartja, illetve gyógymódjukban sem a csodavárást priorizálja. Számtalan receptúrát javasol a különféle ,nyavalyák” enyhítése céljából. Receptgyưjiteményében figyelembe veszi olvasóinak vagyoni helyzetét, melyre való tekintettel több alternatívát is javasol. Erről így ír könyvének előszavában: „E sok különb-különbfél orvosságok közül ha egyiket nem, megszerezhetni a másikat; ha maga házánál nem, feltalálja másénál is; ha egytól nem, öszveszerezheti többtöl. Nem is igazitok mind patikára, hanem nagyrészt házunknál feltalálható szereket igyekeztem a szegényeknek kedvekért elöszámlálni” $[13,15,16]$.

Ugyan a Pax Corporis ma már orvostörténeti érték, semmint orvosi tanácsadó forrás, a lefektetett alapelveknek ma is van létjogosultságuk, például az egészséges életmód tekintetében. Foglalkozik a helyes táplálkozással (az emésztőrendszert megterhelő ételek) és a káros szenvedélyek (dohányzás, túlzott alkoholfogyasztás) egészségre ártalmas következményeivel. Nem tartja jónak „az igen melegen való járást, a hevülés után hirtelen való megbülést, az igen meleg házban való lakást”[13]. A mü élelmezéstudományi és dietetikai vonatkozása tehát inkább a prevenció, a helyes életvezetés és az egyes ételeknek tulajdonított gyógyhatás oldaláról fogalmazódik meg, csakúgy, mintha most, a XXI. században íródott volna.

A Pax Corporis emésztőrendszerrel foglalkozó részében először a „gyomor erötlenségéről, a csömörről és az étel nem kívánásról” ír. Leszögezi, hogy ezek gyakran együtt járó kórképek, egyik a másikból fakad. Mindegyik okát a gyomor ,hidegségében” látja. Gyermekekben a tünetek fellépte súlyosabb, mint felnőttekben. A terápiát „purgatioval” kezdi, tehát hánytatással és hashajtással. Emellett ürömszirupot, ürömbort, narancs levét, friss gyömbért, fodormentát és fahéjat javasol. Kiemeli az étkezés mikéntjének jelentőségét: gyenge gyomrú ember mohón, sokat ne egyen, csak amennyit elbír a gyomra. Az étkezés befejezte után már ne egyen, ne igyon, hagy- 
jon időt, hogy az előbb elfogyasztott ételt meg tudja emészteni a gyomor. Válassza a könnyebben emészthető ételeket. A sütött, aszalt és sós ételeket sorolja az ,ártalmatlanok" közé. Kerülni kell a húsok, halak zsíros részét, a tejet és tejtermékeket, a mézes ételeket, bizonyos gyümölcsöket (dinnye, alma, cseresznye). Javasolja a kesernyés zöldségeket, gyümölcsöket, a salátát, a sóskát, az egrest, a citromot, a narancsot és a gránátalmát, hiszen ezek meghozzák az étvágyat. Ízesítók közül a szerecsendiót, a gyömbért és a fahéjat tartja gyógyhatásúnak [13].

A következőkben „Az Étel kihányásról, nem Emésztésrôl, és Tsuklásról” szól. Fő okként itt is a gyomor gyengeségét említi. Hányás után pirított kenyeret, friss gyömbért javasol ürömmel és mentával. Kiemeli a nádmézzel ízesített fodormentás gránátalmalé jótékony hatásait [13].

Ezután a gyomorfájás taglalása következik. Megkülönbözteti a fájdalmat aszerint, hogy étkezés után alakul ki, vagy pedig éhgyomorra. Elsődleges orvosságként a fogyasztott ételre, italra való odafigyelést említi, hiszen ezek rögtön a beteg gyomorba érkeznek. Könnyen emészthető, jól megfőtt ételek fogyasztása szükséges ilyenkor (például meleg levesek). A fájdalmakat enyhítő füszerek között a fahéjat, a sáfrányt és a szerecsendiót említi. Kiemeli, hogy „,ki ne maradjon” a zsálya, a fenyőmag, a köménymag, valamint a kapor olyan ételekból, melyek ízvilágához illenek ezek. A gyomorfájós ember „bútól, bánattól, haragtól magát igen ójja”, mert ezek is csak a gyomrot gyengítik. Kifejezetten javasolja a székfüvizet, ha ezt nem kapni a patikában, akkor forrásban lévő vízben kell a székfü virágát fözni. Külsőlegesen a gyomortájék bedörzsölését tanácsolja kapor- vagy köménymagolajjal, esetleg mézben fött kömény/kapor magos elegyet kell ruhára kenni és azzal betekercselni a hasat [13].

Ezt követően Páriz doktor leszögezi, hogy nem minden „has-szorulás” kólika, ahogy nem minden hasmenés vérhas. Az igazi kólika nemcsak szorulással, hanem „tekeró, furdaló, és nyilaltató fájdalmak”-kal jár. Az egyik korabeli terápia az ebéd előtt fogyasztott fött aszalt szilva, sok nádmézzel. Hasonló jótékony hatású a vajban, nádmézben fơtt alma. Kólikás fájdalomban segít a köldöktájék köpölyözése vagy melegített tégla, esetleg átmelegített zab és só keveréke a hasra kötözve. A megakadt szeleket a kömény és a babér tudja orvosolni. „A’mi a Diaetát illeti”: meleg ház, szélmentes környezet szükséges. Hideg italt nem ihat a beteg. Önmagában, tisztán vizet ne igyon, inkább kevés bort. Ún. meleg kólikában vizes bort, fahéjjal fött vizet köménnyel és árpával szükséges kortyolgatni. Az étel könnyű legyen, inkább leves, semmint száraz, olajos ételek. Gyenge állatok húsát főzve, nem sütve tanácsos fogyasztani. Az ételkészítés során, ahol lehet, használjon a beteg számára ételt készítő zsályát, petrezselymet, majoránnát, csombort és vadköményt [13].

A továbbiakban a hasmenésről és a vérhasról értekezik. A különféle gyógyreceptek taglalása után újból a diétára tér ki. Mind a hideg, mind a meleg ártalmas lehet, a hangsúly a mértékletességen van. Természetesen könynyen emészthető étel szükséges, inkább száraz, mint leves, inkább sült, mint fơtt. Ajánlott a tej és a tejtermékek fogyasztása [13].

Aranyeres („a vég-Hurkában való Süly”) panaszok esetén minden olyan módszer, praktika, étel és ital javallott, amely a széklet távozását könnyíti, azt lazítja. A lényeg a szorulás elkerülése. A sós, erős, füszeres ételeket mellőzni szükséges, bort nem ihat a beteg. Súlyos esetben a karon való érvágás segíthet a panaszokon a könyv terápiás leírása szerint [13].

A Pax Corporis ötödik kötetében Pápai Páriz Ferenc a májbetegségek gyógymódjairól ír, melyek fóleg a máj „hevesitését”, azaz az epehajtást célozzák: szennával, rebarbarával, ánizzsal, köménnyel, kaporral. Igyon a beteg sok citromos vizet. Szó esik még a sárgaság, a vízkórság (ascites) és a lép betegségeiról is [13].

Pápai Páriz Ferenc Pax Corporis címú múvében hangsúlyosak a táplálkozástudományi és a dietetikai vonatkozások, természetesen egy XVII. századi orvos meglátásai és tudása szerint. Bár a betegségek szempontjából gyưjtötte össze a szükséges terápiákat, sokszor kitért a diéta jelentőségére és minőségére is. Vitathatatlan érdeme, hogy az akkori kor orvosi tudását közérthető nyelven széles körben elérhetővé és az egyszerü nép számára is érthetővé tette. Egész életét a tudásnak, a tanulásnak és a tanításnak szentelte. Életfilozófiáját híven tükrözi jelmondata: „Opere et veritate” - „Cselekedettel és igazsággal”[15].

\section{Irodalom}

[1] Kass J. The picture of Ferenc Pápai Páriz on a stamp. From the stamp collection of Erzsébet Hevesi and Anna Vermes. [Pápai Páriz Ferenc bélyegképe. Hevesi Erzsébet és Vermes Anna bélyeggyújteménye.] Digitális Képarchívum (DKA-068696). [Hungarian]

[2] Dézsi L. Ferenc Pápai Páriz. [Pápai Páriz Ferenc.] A Magyar Történelmi Társaság kiadása, Budapest, 1899. [Hungarian]

[3] Réti E. Great Hungarian doctors. [Nagy magyar orvosok.] Művelt Nép Könyvkiadó, Budapest, 1954; pp. 40-44. [Hungarian]

[4] Ferenc Pápai Páriz Foundation. [Pápai Páriz Ferenc Alapítvány.] Székelyudvarhely. Available from: http://www.papaialapitvany. org/tortenelem [accessed: March 22, 2020]. [Hungarian]

[5] Szállási Á. Páriz Pápai, linguist-lexicographer. [Pápai Páriz, a szótáríró-nyelvész.] Orv Hetil. 1972; 113: 2302-2303. [Hungarian]

[6] Matekovics Gy. The Pax Corporis through the eyes of a dentist. [A Pax Corporis, a fogorvos szemével.] Kaleidoscope Múvelődés-, Tudomány- és Orvostörténeti Folyóirat 2012; 3(5): 18-25. [Hungarian]

[7] Pariz-Pápai. In: Kenyeres Á. (ed.) Hungarian biographical lexicon (1000-1900). [Pápai Páriz Ferenc. In: Kenyeres Á. (szerk.) Magyar életrajzi lexikon (1000-1900).] Available from: https:// www.arcanum.hu/en/online-kiadvanyok/Lexikonok-magyareletrajzi-lexikon-7428D/p-77238/papai-pariz-ferenc-parizpapai-772FC/ [accessed: March 22, 2020]. [Hungarian]

[8] Kótay P. Ferenc Pápai Páriz's way to Dresden. [Pápai Páriz Ferenc drezdai útja.] Commun Bibl Hist Med Hung. 1965; 37: 9-56. [Hungarian] 
[9] Szállási Á. Medical and cultural history studies II. [Orvostörténeti és múvelődéstörténeti tanulmányok II.] Magyar Tudománytörténeti és Egyészségtudományi Intézet, Budapest, 2018; pp. 310-315. [Hungarian]

[10] Sótér I. The history of Hungarian literature from 1600 to 1772. [A magyar irodalom története 1600-1772-ig.] Akadémiai Kiadó, Budapest, 1964. Available from: https://mek.oszk.hu/ 02200/02228/html/02/180.html [accessed: March 22, 2020]. [Hungarian]

[11] Szinnyei J. Life and works of Hungarian writers. X. [Magyar írók élete és munkái. X.] Hornyánszky, Budapest, 1905. Available from: http://mek.oszk.hu/03600/03630/html/ [accessed: March 22, 2020]. [Hungarian]

[12] Pápai Páriz F. Pax Corporis. Kolozsvár, 1690. Available from: https://library.hungaricana.hu/hu/view/RMK_I_1387/ ?query=p\%C3\%Alpai $\% 20 \mathrm{p} \% \mathrm{C} 3 \% \mathrm{Al}$ riz $\% 20$ ferenc $\% 20 \mathrm{pax} \% 20$ corporis\&pg $=4$ \&layout $=s$ [accessed: May 6, 2020]. [Hungarian]

[13] Pápai Páriz F. Pax Corporis. Kolozsvár, 1747. Available from: https://mek.oszk.hu/15200/15273/15273.pdf [accessed: March 22, 2020]. [Hungarian]

[14] Vita Zs. Various editions of Ferenc Pápai Páriz's 'Pax Corporis'. In: Palla Á. (ed.) Publications of the National Library of Medical History 25. [Pápai Páriz Ferenc „Pax Corporis”-ának különböző kiadásai. In: Palla Á. (szerk.) Az Országos Orvostörténeti Könyvtár közleményei 25.] Budapest, 1962; pp. 147-161. [Hungarian]

[15] Balla Á, Pelok B-Gy. To the memory of Pápai Páriz Ferenc. The "Pax Corporis", a home medical book for people. [Pápai Páriz Ferenc emlékezete. A „Pax Corporis”, azaz „Orvos a családban”.] Bulletin Med Sci. 2018; 91: 1-6. [Hungarian]

[16] Kótay P. The Pax corporis is three hundred years old. [Háromszáz éves a Pax corporis.] Korunk 1983; 47: 552-557. [Hungarian]

[17] Szállási Á. Pax Corporis is 300 years old. [300 éves a Pax Corporis.] Orv Hetil. 1990; 131: 2661-2663. [Hungarian]

[18] Bereczki D, Balla Á, Pelok B, et al. International recognition of Ferenc Pápai Páriz as one of the first descriptors of all 4 cardinal signs of Parkinson's disease. [Pápai Páriz Ferenc nemzetközi elismertsége a Parkinson-kór alaptüneteinek egyik első leírójaként.] Orvostud Ért. 2018; 91: 60-66. [Hungarian]

(Molnár Szilvia dr., Budapest, Vas u. 17., 1088 e-mail: molnar.szilvia@se-etk.hu)

\section{„Opere et veritate..." (Pápai Páriz Ferenc) (Cselekedettel és igazsággal...)}

A cikk a Creative Commons Attribution 4.0 International License (https://creativecommons.org/licenses/by/4.0/) feltételei szerint publikált Open Access közlemény melynek szellemében a cikk bármilyen médiumban szabadon felhasználható, megosztható és újraközölhető, feltéve, hogy az eredeti szerző és a közlés helye, illetve a CC License linkje és az esetlegesen végrehajtott módosítások feltüntetésre kerülnek. (SID_1) 